\title{
SPAIN AS THE STATE OF AUTONOMIES. PRINCIPLES BEHIND THE TERRITORIAL ORGANIZATION BETWEEN 1978 AND 1983
}

\begin{abstract}
This article examines the territorial configuration of Spain between 1978 and 1983. The article investigates whether the scope of autonomy granted to the regions inhabited by "the historical nationalities" fulfilled their need of being independent from the central government in Madrid. The article also examines the impact of regionalization on the awakening of local awareness and identification within communities in which it had not existed before. The creation of the Autonomous Communities also affected the party system of Spain in which the major role was played by the regional parties, especially in the construction of the electoral system to Cortes Generales. This allowed strong nationalist groups to become represented in the parliament, enhancing the impact of regionalization on the increase in self-awareness and making the regions fight over their interests in the national arena.
\end{abstract}

Keywords: Spain, Autonomous Communities, Basque Country, Catalonia, Galicia.

\section{INTRODUCTION}

After nearly 40 years of dictatorship of the general Francisco Franco, the promulgation of the Spanish Constitution, on $27^{\text {th }}$ December 1978, crowned the process of democratization which had been initiated in 1975 after the death of the dictator. One of the elements of this phenomenon was a considerable change in the territorial organization of the state which, until then, had rejected any form of regional autonomy. Although the Constitution of 1978 acknowledged "historical nationalities" of Catalonia, the Basque Country and Galicia and granted them the right to autonomy, it simultaneously based the political system on the rule of indissoluble unity of Spanish Nation, in accordance with the Art. 2 of the Basic Law (The Spanish Constitution, 1978). The process of decentralization resulted in the establishment of seventeen Autonomous Communities and Spain became one of the most interesting examples of the regional state (although the three historical nationalities had rejected the term "region" from the very beginning).

The aim of the article is to present the process of the territorial configuration of the country between 1978 and 1983 and the accompanying disputes and doubts concerning the areas of competences given to respective regions. The article also tries to answer the question whether the scope of autonomy granted to the regions inhabited by "the

\footnotetext{
${ }^{1}$ Joanna Jaroszyk, PhD, Faculty of History, Adam Mickiewicz University, Poznań, ul. Uniwersytetu Poznańskiego 7, 61-614 Poznań, Poland; e-mail: jaroszyk@ amu.edu.pl. ORCID: 0000-0003-3285-2163 .
} 
historical nationalities", especially the Basque Country and Catalonia, fulfilled their need of being independent of the central government in Madrid. Another interesting issue addressed in the article is an impact of regionalization on the awakening of local awareness and identification within communities in which it had not existed before.

\section{THE RIGHT TO AUTONOMY IN THE CONSTITUTION OF 1978}

Article 2 of the Spanish Constitution of 1978 acknowledged and guaranteed the right to autonomy to the regions as well as nationalities living in Spain. That was how the process of decentralization of political power started and it led to the establishment of seventeen Autonomous Communities. That way Spain adopted one of the most interesting legal forms of the state ${ }^{2}$. The idiosyncrasy of Spain lies in the fact that it managed to escape a typical classification of the territorial organization which is in step with the characteristics of the federal system (like Germany or Belgium) or unitary system (like Poland or Sweden). At the same time, it is difficult to define Spain as the state of regions as, according to the Constitution, nationalities as well as regions can be autonomous entities. Although the model includes a lot of elements of federation ${ }^{3}$, the Autonomous States (El Estado de las Autonomias), established in 1978, cannot be identified as federation as the Communities did not obtain the constitutional rights, sovereignty or separate judiciary. Therefore, it may be concluded that the Spanish model oscillated between a regional and a federal model, following the philosophy of the former (Alvarez Conde, 1984: 59).

The process of developing the system of regional autonomies went through three phases. The first one covered the period from electing the government of Adolfo Suarez in June 1976 to passing the Basic Law in December 1978. For the Prime Minister Suarez the regional issues were a priority and, therefore, he entered into negotiations with the major opposition parties in order to restore Generalidad (of the Catalonian government, which happened by $41 / 1977$ decree of $29^{\text {th }}$ September) and to establish the Basque General Council (Consejo General Vasco, by 1/1978 decree of $4^{\text {th }}$ January) (Ruiz Robledo, 2003-2004: 712). But as long as the restoration of Generalidad was the historical legitimacy of the Catalonian self-government, the Basque Council was a new body, established to meet the aspiration towards the autonomy of the Basque provinces.

The cooperation with the representatives of the regional political class was also far from typical. The Prime Minister managed to reach an agreement with the Catalonian groups, especially with Josep Taradellas, a leader who enjoyed the greatest trust and who authenticated the actions of the government in the eyes of the Catalonian public opinion. Suarez did not manage to reach a similar pact with the activists of the Basque Nationalist Party (Partido Nacionalista Vasco - PNV) who would have started the negotiations provided that the political prisoners, including terrorists, had been released. Suarez did not want to agree on that (Ruiz Robledo, 2003-2004). Jesus de Leizaol, one of the most prominent members of PNV, only granted his approval for the establishment of the Council.

2 These were: Andalusia, Aragon, Asturias (Prinipado de Asturias), Balearic Islands (Islas Baleares), Extremadura, Galicia, Cantabria, Castilla La Mancha, Castile and Leon (Castilla y Leon), Catalonia (Catalunya), the Basque Country (Pais Vasco), La Rioja (La Rioja), Madrid (Comunidad de Madrid), Murcia (Comunidad de Murcia), Navarre (Navarra), Valencia (Comunidad Valenciana), Canary Islands (Islas Canarias).

${ }^{3}$ Mainly, the reduction of the centralism in favour of the coexistence of two types of organizations, central and territorial, which had a certain degree of legislative and executive power. 
However, what characterized the relation between the central government and PNV was the mutual distrust and PNV's relentless pursuit of autonomy, plus the growing terror used by ETA.

Along the ongoing negotiations, the process of establishing "preautonomies" covering the entire territory of Spain, started. According to Victor M. Perez-Diaz, the main reason behind such strategy was the intention of reducing the Catalonian and Basque problem, which could be proven by the fact that the system in question was also introduced in the regions which did not show any interest in it. The government in Madrid believed that it would be easy to manipulate the regional political class (Perez-Diaz, 1996: 220). However, setting up preautonomies on the territory of the entire country was a complicated issue as there was the same number of arguments for and against the introduction of the general system. Among the numerous drawbacks of such a solution were the lack of historical legitimacy which could lay the foundation for the new system, the absence of the representatives of nationalist parties in Cortes Generales from the remaining territories of Spain (apart from Catalonia and the Basque Country), the Italian experience after the $2^{\text {nd }}$ World War and the difficulties concerning the integration into the work of the Constituent assembly. On the other hand, the political and social willingness to establish selfgovernments was becoming more and more common. In various parts of Spain, deputies and senators, appointed on $15^{\text {th }}$ July, set up "the parliamentary congregations" demanding "preautonomy", which often received social support, e.g. in Andalusia where, on $4^{\text {th }}$ December 1977, there were demonstrations in favour of electing the autonomous government. The tactical aspect of the general system was dulling the vigilance of the army and other "actual authorities" which were concerned about the reclamation of Basques and Catalonians (Ruiz Robledo, 2003-2004: 713).

At the beginning of January 1978, the Official Gazette of Cortes Generales published the initial project of the Constitution which, within the discussed scope (i.e. the territorial configuration of the political power), received a great number of amendments whose postulates were frequently contradictory. Some of them expressed the concerns of political class who was worried that the territorial unity of the country would be lost, others expressed the desire for introducing confederation (Ruiz Robledo, 2003-2004). As a result, as much as the project clearly recognized the right to the autonomy of the nationalities and regions and served as the uniform procedure for establishing autonomous territories, the final text of the Constitution became chaotic and complicated, causing serious problems with its interpretation.

For example, a number of "security measures" against the autonomies was introduced, mainly by the extensive article 2 of the General Law according to which: "The Constitution is based on the indissoluble unity of the Spanish Nation, the common and indivisible homeland of all Spaniards; it recognizes and guarantees the right to self-government of the nationalities and regions of which it is composed and the solidarity among them all". Thus, the concept of the state was based on four fundamental principles:

- The principle of indissoluble unity of the Spanish nation and the existence of the common and indivisible homeland of all Spaniards,

- The principle of the right to autonomy,

- The principle of solidarity,

- The principle of cooperation. 
The first principle was the most crucial as it indicated a uniform character of the state and denied respective regions the right to secession. Moreover, in section 145, the legislator introduced a ban on setting up the federation of autonomous communities and the paragraph 2 introduced an additional "safety brake" by obliging the Communities to define the rules of cooperation (Łabno-Jabłońska, 1996).

The approved methods used to establish self-governments led to the creation of the privileged autonomies which were equipped with a high degree of self-determination and did not have to meet the requirements imposed on other territories. What is more, the Constitution raised the possibility of creating first degree (de primer grado) and second degree (de segundo grado) autonomies. The differences between them lay in the political character of the former and the administrative character of the latter. According to the Second Interim Provision of the Basic Law, the privileged autonomies (Catalonia, the Basque Country and Galicia) were waived from the requirement of the autonomous initiative which was replaced by the agreement between preautonomous bodies. This made it possible to move to the second stage of creating self-governments - i.e. the preparation of the Autonomous Statute ${ }^{4}$. Moreover, according to the Resolution, the privileged communities did not have to meet the requirements set down in the article 148, section 2 (introducing five-year period after which the autonomies could gradually increase the scope of their competences) and, therefore, could reach the highest degree of self-determination without taking the dividing line set up in the Basic Law into account. The scope of competences acquired that way encompassed the issues defined in: art. 148.1; matters of exclusive State jurisdiction according to art. 149.1; competences included in the Statutes according to the art. 149.3 and competences acquired after passing the Statutes according to the art. 150 of the Constitution ${ }^{5}$.

\footnotetext{
${ }^{4}$ Such a procedure was included in the Second Interim Provision: "The territories which in the past have, by plebiscite, approved draft Statutes of Autonomy and which at the time of the promulgation of this Constitution, have provisional autonomous regimes, may proceed immediately in the manner provided in clause 2 of Article 148, when agreement to do so is reached by an absolute majority of their pre-autonomous higher corporate bodies, and the Government is duly informed. The draft Statutes shall be drawn up in accordance with the provisions of Article 151, clause 2, when so requested by the pre-autonomous corporate body."

5 Article 148 of the Spanish Constitution of $27^{\text {th }}$ December 1978, (The Spanish Constitution, 1978):

1. The Autonomous Communities may assume competences over the following matters:

1) organization of their institutions of self-government;

2) changes in the municipal boundaries within their territory and, in general, the functions appertaining to the State Administration regarding local Corporations, whose transfer may be authorized by legislation on local government;

3) town and country planning and housing;

4) works of benefit to the Autonomous Community, within its own territory;

5) railways and roads whose routes lie exclusively within the territory of the Autonomous Community and transport by the above means or by cable which also fulfils the same conditions:

6) ports of haven, recreational ports and airports and, in general, those which are not engaged in commercial activities;

7) agriculture and livestock raising, in accordance with general economic planning;

8) woodlands and forestry;

9) environmental protection management;
} 
The second form of self-government, so-called first degree Autonomies, encompassed the territories which did not use the facilitations defined in the Second Interim Provision but had the possibility to reach the same degree of self-determination after fulfilling certain, sometimes strict, requirements. The autonomous initiative was undertaken in accordance with the art. 151.1 of the Constitution, i.e. within six months from passing the first resolution on the said initiative by one of the interested local bodies. Next, such initiative had to be ratified in a referendum by the absolute majority of the electors in each province of the future community ${ }^{6}$. Another step towards autonomy, i.e. the preparation of statutes, was taken in accordance with the procedure defined in the art. 151.2 (similarly as in the case of the privileged communities). The only difference lay in the fact that it was the

10) planning, construction and operation of hydraulic projects, canals and irrigation of benefit to the Autonomous Community; mineral and thermal waters;

11) inland water fishing, the shellfish industry and aquaculture, shooting and river fishing;

12) local fairs,

13) promotion of the economic development of the Autonomous Community within the objectives set by national economic policy;

14) handicrafts,

15) (......), 16) (.......)

17) the promotion of culture, of research and, when applicable, the teaching of the language of the Autonomous Community;

18) (.........), 19) (..........),

20) social assistance,

21) (.......), 22) (............).

2. After five years have elapsed, the Autonomous Communities may, by amendment of their Statutes, successively expand their powers within the framework established in Article 149.

Article 49.3 Matters not expressly assigned to the State by virtue of the present Constitution may fall under the jurisdiction of the Autonomous Communities by virtue of their respective Statutes. Matters for which jurisdiction has not been assumed by the Statutes of Autonomy shall fall within the jurisdiction of the State, whose laws shall prevail, in case of conflict, over those of the Autonomous Communities regarding all matters over which exclusive jurisdiction has not been conferred upon the latter. State law shall, in all cases, be supplementary to that of the Autonomous Communities.

Article 150

1. The Cortes Generales, in matters of State competence, shall confer upon all or any of the Autonomous Communities the power to enact legislation for themselves within the framework of the principles, bases and guidelines established by State law. Without prejudice to the competence of the Courts, each basic law shall contain the method of control by the Cortes Generales over the Autonomous Communities' legislation.

2. The State may transfer or delegate to the Autonomous Communities, through an organic law, powers appertaining to it which by their very nature lend themselves to transfer or delegation. The law shall, in each case, provide for the appropriate transfer of financial means, as well as specify the forms of control to be retained by the State.

3. (................)

${ }^{6}$ Such strict requirements for the autonomous initiative resulted from the conviction of the creators of the Constitution that the path to autonomy, defined in the article 151.1, will be followed by way of exception and the territories that are not "historical communities" (like Catalonia, the Basque Country and Galicia for which the special procedure of the Second Interim Provision was prepared) will take the path to autonomy defined in the article 143.2 which is less demanding but which will make them obtain the autonomy after a longer period of time (Alvarez Conde, 1984). 
government that summoned all the Senators and Deputies for the purpose of drawing up an adequate draft ${ }^{7}$. Once the draft was accepted by the Constitutional Committee of Congress, it was submitted in a referendum to the electorate of the province (majority of validly cast votes was enough). After that, it was remitted to the Cortes Generales which decided upon the text by means of a vote of ratification. If all the above mentioned requirements were met, the first degree community reached the same degree of independence as the privileged communities. The institutional organization of the autonomy was identical and it was based on the Legislative Assembly and the Governing Council with the President as its head $\left(\right.$ art. $\left.152.1^{8}\right)$.

According to the creators of the Constitution, the second degree autonomous communities were to encompass the majority of the territory of the state, especially those areas where self-governing aspirations did not have a long tradition. The autonomous initiative was defined in the art. 143.2 which simplified it in relation to the requirements laid down in the art. 151.19. The procedure of drawing up the statutes of that kind of communities was defined in the art. 146, which left no room for negotiations. Once the preautonomous bodies submitted the proposal, the final decision was solely made by the Cortes Generales. In this case, we can talk about the autonomy granted by the state and not about the agreement between equal partners (Alvarez Conde, 1984: 409). The competences listed in the art. 148 were initially the only competences granted to the second degree autonomies. However, it did not mean that the Constitution left no room for expanding autonomy as, in accordance with the art. 148.2, after five years and the reform of the autonomous statutes, the communities could take over the remaining prerogatives guaranteed in the Basic Law.

\section{TWO MODELS OF AUTONOMY AND THE SUCCESSIVE PHASES OF REGIONALIZATION}

The approved models of autonomy led to the creation of the system called "asymmetric federalism" (federalismo asimetrico). Augustin Ruiz Robledo emphasized that this regulation was not free from a number of paradoxes. What was the purpose of holding a referendum, with the quorum difficult to achieve, in order to obtain the competences five years faster than the remaining communities which would obtain them anyway, ${ }^{10}$ ?

7 The draft Statute was then remitted to the Constitutional Committee of Congress where it was possible to negotiate its definitive formulation with the cooperation and assistance of a delegation from the Assembly which has proposed it (art. 151.2, item 3).

8 Interestingly, the Constitution expanded the autonomous competences in relation to the regulations listed in the project of the Basic Law, introducing the Legislative Assemblies as the bodies of the Communities, which granted them the legislative powers (Ruiz Robledo, 2003-2004).

9 In such a way that the article 143.2 did not require the confirmation of the initiative in a referendum which, according to the article 151.1, had to be rattified by the absolute majority of the electors in each province. Another facilitation was the regulation of the First Interim Provision which all territories could refer to. According to this provision, in the territories with a provisional Autonomous regime the resolution of the higher corporate bodies could replace the autonomous initiative defined in the article 143.2 (which granted this right to the adequate Provincial Councils or inter-island bodies).

${ }^{10}$ It can also be assumed that, at least theoretically, the second degree autonomies achieved greater scope of autonomy as they could freely define their bodies on the basis of the article 147. The article 152 of the Constitution did not apply to them. Eventually, they adopted the identical body 
Moreover, chapter $8^{\text {th }}$ of the Basic Law, as the compromise between various national and regional parties, did not solve the problem of conferring autonomous powers successfully, leaving the decision to the subsequent political negotiations. Nevertheless, the Constitution was passed by the parliament and ratified in a referendum in 1978. The Basque PNV called for a boycott of the referendum as, against their demands, the Basic Law did not mention "the historical rights" which would make negotiations over gaining the right to self-determination possible (Perez-Diaz, 1996).

The next phase of regionalization covered the period from the ratification of the Basic Law to the coup attempt in 1981. This period was characterized by two parallel processes. Firstly, the Prime Minister Suarez had to deal with the attempts at forcing the draft statutes prepared by the nationalists (Guernica and Sau Statutes) which deprived the central authorities of as many powers as possible and even reduced the freedom in carrying out foreign policy. Simultaneously, the process of activation of regional awareness among other regions was taking place. The main source of the phenomenon was the concern that a favourable treatment of Basques and Catalonians would have a negative effect on the remaining regions of Spain which argued about, e.g. taxes, investments, energy or natural resources. Along the pursuit of reducing economic inequalities, the claim of making the statutes of respective regions equal was also made. Some people could not accept the fact that some regions (Catalonia, the Basque Country and Galicia) would be granted full autonomy, whereas others only partial autonomy. Moreover, some regions would gain it very fast, whereas other slowly and with difficulty (which was suggested in the art. 143 and 151 of the Constitution), all the more that already in 1979 the preferential Basque and Catalonian statutes were passed ${ }^{11}$. As the result, in the referendum of February 1980, Andalusians rejected the governmental proposal of the partial autonomy for that region ${ }^{12}$. From that moment, the competition for the prestigious status of the nationality intensified in the entire country. However, as Perez-Diaz emphasized, it was difficult to say whether the feeling was authentic or whether it was just a projection of regional political class. Those events, as well as the intensification of ETA terrorist attacks (whose activity gained the support of $15 \%$ of the electorate) led to the unrest in the army, the cumulation of which was the coup attempt in February 1981.

The third phase of regionalization started with the coup attempt. As the result of the mediation of the king and the negotiations with the military powers, the coup was put down by the army. According to Victor M. Perez-Diaz, the directly expressed strategy was simple: "the military powers unambiguously informed the political class that they would force them to make a moral commitment to prioritize the pursuit of preserving the unity and territorial integrity of Spain" (Perez-Diaz, 1996). Although it would be possible to challenge that

structure as the autonomies established on the basis of the article 151 of the Constitution (Ruiz Robledo, 2003-2004).

11 The whole procedure went exceptionally fast. On $22^{\text {nd }}$ December 1978 (three days before the Constitution was adopted) the Basque members of the parliament passed the draft Statute which was remitted to the Cortes Generales on $29^{\text {th }}$ December, i.e on the day the Constitution entered into force. The Catalonian members of the parliament did not stay behind; they remitted their project an hour later. The statute of Galicia was drawn up only after the parliament election on $1^{\text {st }}$ March 1979 and it was remitted to the Cortes Generales in June 1979 (Ruiz Robledo, 2003-2004).

12 On 5th December 1978, eleven Andalusian groups, from Accion Popular to the extreme left, signed Pacto de Antequera, the agreement proposed by the president of the Preautonomous Junta, Placido Fernadez Viagas, in order to obtain the full autonomy (Ruiz Robledo, 2003-2004). 
thesis, the fact was that, from that moment, the nationalist rhetoric gave way to the systematized work towards passing authorizations to the autonomous regions and imposing a legal framework which would protect the authority of the central government. The victorious Andalusian fight over the expansion of the scope of autonomy created "a domino effect", which meant that other regions had similar expectations. As the result, the government of the Union of the Democratic Centre (UCD) and the Spanish Socialist Workers' Party (PSOE) signed an agreement in order to unify the model of autonomy in the entire country on $31^{\text {st }}$ July 1981. A new law was introduced (LOAPA - An Organic Law related to the Process of Harmonizing the Autonomization Process) and it served as a model to many regional statutes passed in the coming years (although Basques and Catalonians challenged that law to the Constitutional Tribunal which decided that it was against the Constitution of 1983) (Santamaria Arinas, 2015).

As a result, a series of pacts between the central authority and various regional political elites was made. They included: chapter $8^{\text {th }}$ of the Constitution, the Catalonian and Basque statutes of 1979 and the remaining statutes of various regions and nationalities passed at a later time. What has to be added to that group of general standards are the institutions which regulated the process of ongoing negotiations on passing the resources to the regional authorities by the central administration. Thanks to the regional pacts, the national integration was strengthened. Nearly all the regional movements and a large part of peripheral nationalist movements were included in the political system. Although still at a margin of the political system, the Basque PNV showed certain readiness to cooperate with the central government, which was expressed by the limited legal pact made between the president of the autonomous Basque government, Jose Antonio Ardanza, and PSOE, the Basque authorities. However, PNV kept demonstrating the need for the final renegotiation of the statute.

The result of the third phase of regionalization was the resignation from the controversial division into political autonomies (first degree) and administrative autonomies (second degree) in favour of the differentiation between a fast road (autonomias de via rapida) and slow road (autonomias de via lenta) towards autonomy. By 1983, seventeen Autonomous Communities were established that way and the last statute of Kasilla and Leon was passed in February 1984. Segovia joined that community a month later under the Organic Law 5/1983 (Leguina Villa, 1985).

\section{SUMMARY}

The system of autonomy created between 1978 and 1983 radically changed the territorial organization of the country, affecting the political and party system of Spain. However, a wide scope of autonomy, granted to the Basque Country and Catalonia, did not satisfy their pursuit of self-determination expressed from the very beginning of democratization. From the point of view of those regions, the constitutional rule of indissoluble unity of the Spanish Nation was like "the original sin", making it impossible for the nationalist parties to fully accept the Basic Law and the constitutional order which ruled out the secession of the regions. Although further compromises in favour of the Communities were made and greater competences were passed in the coming years, such attitude did not change. The tension between the central government and the Basque Country and Catalonia reached its apogee every few years, which was caused 
by the regions demanding increased autonomy or even secession. It finally led to the events of $29^{\text {th }}$ December 2004 when the Basque parliament accepted the project (so-called Ibarretxe Plan) which assumed the proclamation of the independent Basque Country ${ }^{13}$. According to the plan, the existing autonomous statute would be rejected and replaced by the new one which would proclaim "a free union" between the Basque Country and Spain. Soon after that, in October 2005, the Generalitat parliament passed a new statute which defined Catalonians as "the nation" existing within "the multinational and federal state" and emphasized Catalonians' right to freely decide about their future" (Propuesta, 2005). On the other hand, the referendum for independence, held in 2017, and the political crisis resulting from the increased separatist tendencies showed that the problem of the regional nationalism in Spain was still not solved and expanding the scope of autonomy did not make the problem any less serious. It was because the policy of concessions and compromises between the central government in Madrid and the nationalist powers of the discussed regions was always "a play for time" and the main problem, i.e. the demand to acknowledge the national subjectivity and the right to self-determination, was still not solved.

The creation of the Autonomous Communities also affected the party system of Spain in which the major role was played by the regional parties, especially in the construction of the electoral system to Cortes Generales. Thanks to the above mentioned system, strong nationalist groups had their representatives in the parliament and they became so-called "the tongue in the weight", especially for the cabinets which did not have an absolute majority. Not only was it the case of the regional parties of the Basque Country and Catalonia but also of Galicia, Aragon or the Canary Islands. This proves the thesis about the impact of regionalization on the increase in self-awareness of the regions which also fought over their interests in the national arena.

\section{REFERENCES}

Alvarez Conde, E. (1984). El regimen politico español. Madrid.

Keating, M., Bray, Z. (2006). Renegotiating Sovereignty: Basque Nationalism and the Rise and Fall of the Ibarretxe Plan. "Ethnopolitics", 5 (4).

Leguina Villa, J. (1985). El acceso forzoso a la autonomía política. "Revista Española de Derecho Constitucional", 14.

Łabno-Jablońska, A. (1996). Iberyjska droga do demokracji. Warsaw.

Perez-Diaz, V.M. (1996). Powrot spoleczenstwa obywatelskiego w Hiszpanii. Cracow.

Propuesta de reforma del Estatutode Autonomía de Cataluña. Access on the internet: http://estaticos.elmundo.es/documentos/2005/10/01/estatuto_castellano.pdf.

Ruiz Robledo, A. (2003-2004). Veinticinco anos de Estado Autonomico. "Revista de Derecho Politico (Numero monografico. Balance de la Constitucion en su XXV Aniversario)”.

\footnotetext{
13 The moderate PNV nationalists, who ruled from 1979, prepared the Ibarretxe Plan in 2002, and the Basque Prime Minister, Juan Jose Ibarretxe, subordinated his political program to it (Keating, Bray, 2006).
} 
Santamaria Arinas, R.J. (2015). Del ruido de sables a la algarbia de los mercados: la LOAPA vista desde las atipicas armonizaciones de hoy. "Iura Vasconiae", 12.

The Spanish Constitution of $27^{\text {th }}$ December 1978 (1978). Boletin Oficial del Estado, 311.

DOI: $10.7862 /$ rz.2020.hss.40

The text was submitted to the editorial office: November 2020.

The text was accepted for publication: December 2020. 